\title{
Palatine Tonsillar Epidermoid Cyst- Mimicking Cystic Tumor
}

\section{Kistik Tümörü Taklit Eden Palatin Tonsilin Epidermoid Kisti}

\author{
Kodihalli Nagaraju Kusuma1 ${ }^{1}$, Nagendra Chandana ${ }^{1}$, S Vijay Shankar ${ }^{1}$
}

${ }^{1}$ Adichunchanagiri Institute of Medical Sciences, Department of pathology, Mandya, Karnataka, India

Address correspondence to: $S$ Vijay Shankar, Professor and HOD, Department of Pathology, Adichunchanagiri Institute of Medical sciences, Adichunchanagiri University, Mandya, Karnataka, India e-mail: drvijayshankar@bgsaims.edu.in

Geliş Tarihi/Received: 6 August 2021 Kabul Tarihi/Accepted: 1 September 2021

\section{Öz}

Epidermoid kistler, epidermal elemanların dermal ve daha derin dokulara implantasyonu ile oluşurlar. Baş ve boyun bölgesinde görülme sıklığı \%1,6 ile \%7 arasında değişmektedir. Tonsil bölgesinde görülmesi son derece nadirdir, yani neredeyse \%0.01'den azdır. Fetal dönemde konjenital bir lezyon olarak meydana gelebilirler veya travmaya bağlı ya da cerrahi sonrası implant olarak edinsel şekilde ortaya çıkabilirler. Bu olgu sunumunda, daha önce bilateral tonsillektomi öyküsü olan ve boğaz ağrısı şikayeti ile başvuran 46 yaşındaki erkek hastada teşhis edilen epidermoid kisti sunacağız.

Anahtar Kelimeler: Epidermoid kist, palatin tonsil, otalji

\section{Abstract}

Epidermoid cyst refers to the implantation of epidermal elements into the dermal and deeper tissues. In head and neck, incidence ranges from 1.6 to $7 \%$. In the tonsillar area it is extremely rare i.e less than $0.01 \%$. They occur in fetal period as congenital lesion or as an acquired lesion either due to a trauma or as post surgery implant. In this case report, we will discuss the epidermoid cyst, in a 46-year-old male who presented with history of pain in the throat with previous history of bilateral tonsillectomy.
Cite this article as: Kusuma KN, Chandana N, Shankar SV. Palatine Tonsillar Epidermoid Cyst- Mimicking Cystic Tumor. Selcuk Med J 2021;37(3): 283-286
Disclosure: None of the authors has a financial interest in any of the products, devices, or drugs mentioned in this article. The research was not sponsored by an outside organization. All authors have agreed to allow full access to the primary data and to allow the journal to review the data if requested. 


\section{INTRODUCTION}

Palatine tonsil is located on either side of the oropharynx between the palatoglossal and palatopharyngeal arches (1).There are wide variety of cysts that can occur in the tonsils which includes retention cysts, dermoid cysts, lymphoepithelial cysts and hydatid cysts, However retention cysts are most common (2).

The term epidermoid cyst was defined by Roser (3). These cysts are benign. They can develop either from abnormal epithelial components of ectodermal tissue or implanted epithelium arising after trauma or surgery (4). Epidermal cysts can occur anywhere in the human body, however they are most common in head and neck region. In pharynx the occurrence of these cysts are very rare. The incidence in intraoral region is very low $(0.01 \%)$. They are most commonly seen in the floor of the mouthand labial, lingual or buccal mucosa (5). Most common presentation is swelling and pain, other less common symptom is referred pain, which might be challenging symptom as it leads to a misdiagnosis. In this case report, we will discuss the epidermoid cyst, in a 46-year-old male who presented with history of pain in the throat with previous history of bilateral tonsillectomy.

\section{CASE REPORT}

A 46-year-old male presented with history of pain in the throat since one month which aggravated in the night. He also had a burning sensation in the

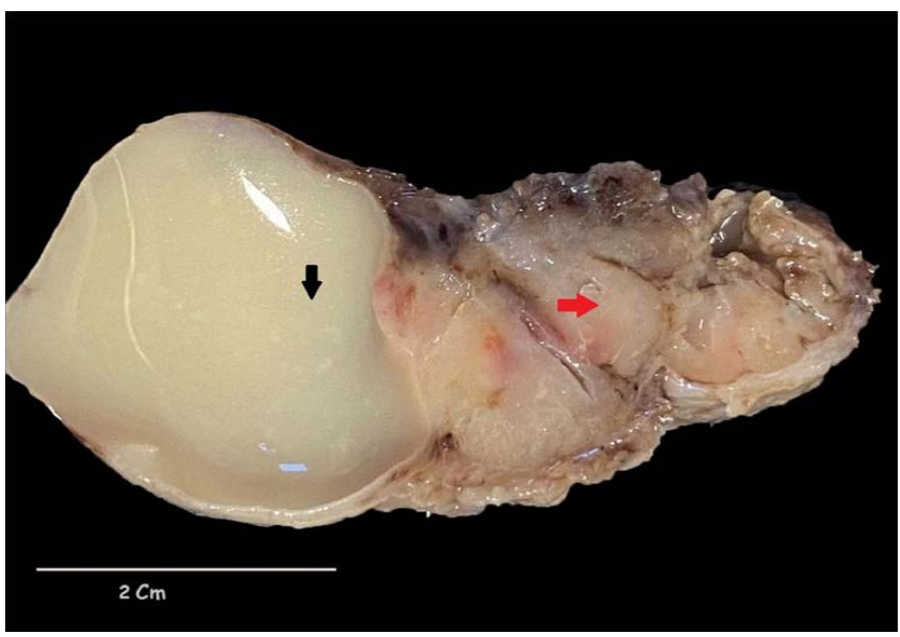

Figure 1. Gross image showing remnant tonsil ( red arrow) with cyst filled with pultaceous material( black arrow)

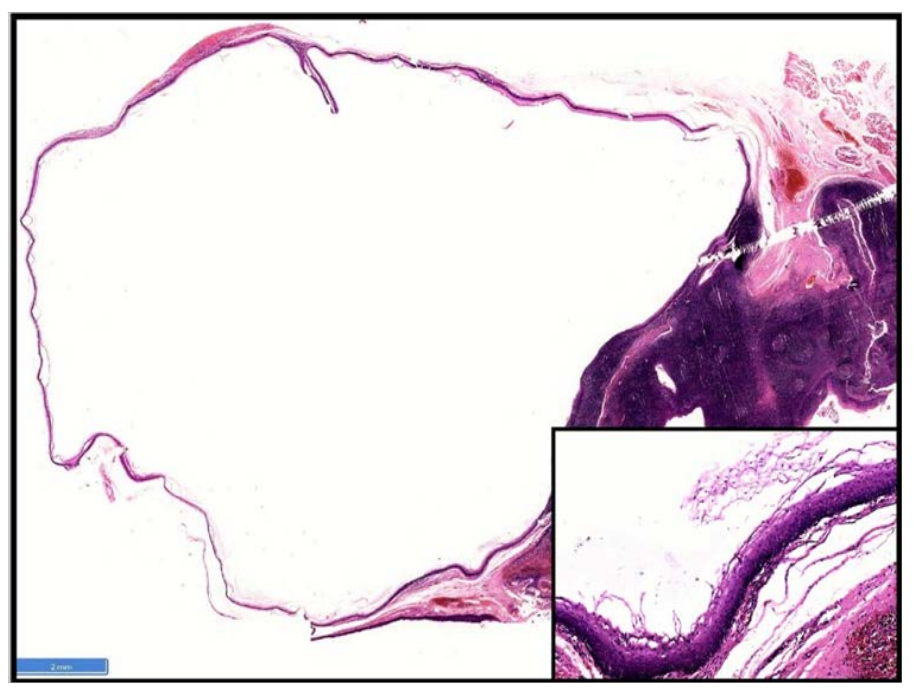

Figure 2. Histopathological examination under low power ( H\&E X 20) and high power (inset -H\&E X $100)$ showing tonsillar tissue within which are cavity lined by stratified squamous epithelium

throat. Later swelling was noticed by the patient.He gave a history of bilateral tonsillectomy two years back after being diagnosed of chronic tonsillitis. Routine investigations were unremarkable. Ear and nose examination were within normal limits. On throat examination right tonsillar area was enlarged and cystic. Clinical diagnosis of tonsillar cyst was made for which patient underwent excisional biopsy. Histopathological examination was done on the specimen sent. On gross examination the specimen consisted of remnant tonsillar tissue attached with a cyst together measuring $3.5 \times 1.5 \times 0.5 \mathrm{~cm}$. The cyst measured $2 \times 1.5 \times 0.5 \mathrm{~cm}$. External surface - grey brown, homogenous. Cut surface was solid and cystic (Figure 1). Cyst was filled with grey yellow thick pultaceous material. Microscopic examination revealed a cyst which lined by stratified squamous epithelium and was filled with keratin flakes, cyst macrophages and few lymphocytes (Figure 2). Remnant tonsil showed hyperplastic lymphoid follicles with prominent germinal centres suggesting features of chronic tonsillitis. There was no recurrence on 6 months of followup.

\section{DISCUSSION}

The palatine tonsil is required for the antimicrobial defense mechanism of the body. Several diseases 
are common in tonsil, among which chronic tonsillitis is the commonest one which clinically presents as tonsillar hypertrophy. Tonsillar tumors, tumors of parapharyngeal space, infectious etiology and inclusion cysts are the various differential diagnosisof tonsillar hypertrophy (2). Pathologically, Cyst is defined as fluid filled cavity. Contents may be solid, semisolid or gaseous. Several cystic lesions can develop in tonsils, which can be broadly classified as infectious and non-infectious (5).

Epidermoid cyst refers to the implantation of epidermal elements into the dermal and deeper tissues. They are benign in nature. Epidermoid cysts are also termed in different names such as epidermal cyst, epidermal inclusion cyst. epithelial cyst, keratin cyst, or sebaceous cyst. These cysts are lined with simple squamous epithelium and its wall does not contain skin appendages unlike dermoid cysts (5). In head and neck region, the incidence of epidermoid cyst varies between 1.6 and $7 \%$. In the tonsillar area incidence is extremely rare i.e less than $0.01 \% .6$ They can be seen at any age. Majority are in the age between 10-35 years. The male to female ratio in literature is $1: 4(4)$.

The exact etiopathogenesis of epidermoid cyst is not known. However, the most popular theory is "epithelial implant theory". Epithelial implant is a possibility and can occur due to abnormal inclusion of cells during surgery/trauma. Developmentally it can be due to the epithelia remnants isolation during the closure of first and second branchial arches in the midline (7). Gardner syndrome, basal cell nevus syndrome, and pachyonychia congenital are few of the hereditary syndromes which are associated with these cysts (8). In tonsil, these cysts present as a painless, asymptomatic mass or occasionally throat pain. Sometimes it can also present as referred otalgia which poses a difficult diagnostic challenge. The most common causes of referred otalgia are acute pharyngitis, tonsillitis, peritonsillar abscess, temporomandibular joint syndrome, dental disease and cervical spine arthritis. Therefore, detailed history and careful examination is must to rule out these conditions (5).

In most cases the cyst is not evident on clinical examination but only tonsillar hypertrophy may be prominent $(3,6,8)$. Parapharyngeal space, infectious etiology, lymphoepithelial cyst, dermoid cyst, papilloma and tonsillar carcinoma are considered as differential diagnosis of tonsillar hypertrophy. Histopathological examination is required to differentiate these entities, hence thorough gross and microscopic examination of every resected tonsillar mass is important. Dermoid cysts shows adnexal structure along with lining epithelium whereas lymphoepithelial cyst shows lymphoid population $(6,8)$. Complications of these cysts includescyst rupture or infection in the long standing untreated cases. When its infected the cyst wall may also contain lymphocytes, macrophages, neutrophils along with keratin debris. Rarely cyst rupture leads to aspirational pneumonia (5).

Tonsillar cysts can be diagnosed based on imaging and can be aided by fine needle aspiration. However, excision biopsy is the confirmatory test which aids in thorough examination and helps to rule out any underlying malignancy (6). Generally, treatment is not required for asymptomatic patients. Surgical excision of the cyst or tonsillectomy is the treatment of choice for symptomatic patients. Utmost care should be taken while excising cyst as its contents have an irritating effect on the surrounding fibrovascular tissue. The recurrence of the cyst is very rare if the cyst is excised completely (6). Rarely malignancy can be developed within the cysts in chronic long standing cases. Presence of sudden increase in size helps in suspecting malignancy. This risk of malignancy attributes to $7 \%$ in adults. Asymmetrical tonsillar enlargements in adults is a high-risk sign to look for malignancy in detail (9). Hence through detailed histopathological examination is needed for cyst excision.

\section{CONCLUSION}

Tonsillitis is a common entity in all age groups, however histopathological examination plays a major role in detecting non neoplastic and neoplastic lesions of the tonsil. Epidermoid cyst is a rare entity in tonsil but should be always evaluated properly for definitive treatment and to avoid complications.

Conflict of interest: Authors declare that there is no conflict of interest between the authors of the article.

Financial conflict of interest: Authors declare that they did not receive any financial support in this study.

Address correspondence to: S Vijay Shankar, Professor and HOD, Department of Pathology, Adichunchanagiri Institute of Medical sciences, Adichunchanagiri University, Mandya, Karnataka, India

e-mail: drvijayshankar@bgsaims.edu.in 


\section{REFERENCES}

1. Drake R, Vogl AW, Mitchell AW. Gray's anatomy for students. 3rd edition. Philadelphia: Elsevier Health Sciences, 2009:139-41.

2. Kilinç AN. Epidermoid cyst of the palatine tonsil: An incidental rare finding and literature review. Kahraman Maras Sütçü İmam Üniversitesi Tıp Fakültesi Dergisi 2020;15(3):112-5.

3. Gulia SP, Lavanya M, Kamidi V, et al. Epidermoid cyst of the tonsil: An incidental finding. International Journal of Advances in Case Reports 2015;2(12):777-9.

4. Erol K, Erkan KM, Tolqa D, et al. Epidermoid cyst localized in the palatine tonsil. J Oral Maxillofac Pathol 2013;17(1):148.

5. Mathew AS, Gowda BC, Sridhar A. Multiple epidermoid cysts in the palatine tonsil causing referred otalgia: A case report. JMSCR 2019;7(1):861-64.
6. Bouatay R, Jellali S, Abdejelil N, et al. Epidermoid cyst of the tonsil: A rare finding. The Pan African Medical Journal 2019;34:4.

7. Dhiraj B Nikumbh, Roopali D Nikumbh, Hemant More. Intratonsillar multiple epidermal inclusion cysts-A tumor mimic. Archives of Cytology and Histopathology Research 2017;2(1):18-20.

8. Rajendran R. Developmental disturbances of oral and paraoral structures. In: Rajendran R, Sivapathasundhram B, Eds. Shafer's Textbook of Oral Pathology. 5th Edition, Amsterdam:Elsevier, 2007,67.

9. Macnamara M. Acute and chronic pharyngeal infections. In Gleeson M (ed). Scott-Brown's Otorhinolaryngology.7th ed. London: Hodder Arnold 2008;1981-2025. 